\title{
Effect of Functional Core Conditioning Training on Hiking at Sailing Radial
}

\author{
Dr.Sarah Hassan El Beih \\ Department of Aquatic Sports Training, \\ Faculty of Physical Education, Helwan University, \\ Cairo, Egypt
}

\author{
Dr.Aliaa Emad Fakhry \\ Department of Biological Sciences and Sports \\ health, Faculty of Physical Education, Helwan \\ University, Cairo, Egypt
}

\section{Introduction}

Sailing, has complex nature (Sjøgaard, Inglés, \& Narici, 2015) as body weight is used by sailors to balance in dinghy boats (Bojsen-Møller et al., 2015), which requires great strength in core-stability, core strength and core endurance (Hibbs et al., ; Sharrock et al., 2011). Continual control for the boat by repeated ropes pulling that requires building upper-body strength along with managing lots of tools, whereas reading competitors' tactics, waves and wind. Reacting by fast decision thatneeds to improve fast decision-making skills; apart with the Cardio fitness as in a race burns around 400 calories per hour that will increase stamina and heart rate, especially if it is very high wind (Sjøgaard et al., 2015)

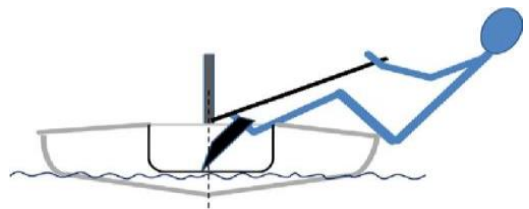

Figure 1. Hiking technique.

The greatest exerted physical maneuver which is mandatory in dinghy sailing is thehiking (Figure 1) (Larsson et al., 1996; Sekulic et al., 2006 ; Chicoy \& Encarnación-Martínez, 2015). Effect of the wind on the sail causes the boat to heel, which increases its resistance and decreases its speed (De Vito et al., 1993; Sekulic et al., 2006). Sailors hanging over the side of the boat with their upper limb weight (Day, 2017), to exert the greatest physical maneuver which is mandatory in dinghy sailingby hiking (figure 1) (Chicoy \& 
Encarnación-Martínez, 2015) ; Larsson et al., 1996;Sekulic et al., 2006 ; (Rodek et al., 2012), As hiking characterized by strong isometric contractions of the muscles including quadriceps, hamstrings, abdominaland paravertebral muscles (Tan et al., 2006 ; Callewaert et al., 2015 ; Larsson et al.,1996) which is required in the vast majority of races. Hiking maneuver is required to increase boat speed by using hiking fundamental in order to correct the boat position with the aim of facilitating planning and, therefore helps in more upright boat position which will enhance its performance as well as improving the acting drag forces on the sail (Day, 2017) to improve speed, through an efficient hiking technique results in less friction between boat and water (Sprada et al., 2007, De Vito et al., 1993; Sekulic et al., 2006 ; (Cunningham \& Hale, 2007) ; Chicoy \& Encarnación-Martínez, 2015).

A race takes place from 3-4 knots of intensity up to 25-30 knots, (Blackburn, 1994).The hiking position is not held more than 20 seconds continuously, then change through three different positions: sitting upright, hiking in a vertical position and hiking with the body inclined backwards (Felici et al., 1999; Blackburn, 2006; and Sekulic et al., 2006).

The sailor sits upright while sailing in the direction of the course (downwind) in anywind condition, crosswind (perpendicular to the wind) on the run (oblique to the wind) and upwind (in the opposite direction to the wind at $45^{\circ}$ ) in light winds (from0 knots to 7 knots). The sailor hikes on the close-hauled course in medium winds inan upright position (from 8 knots to 12 knots) as well as in crosswinds and on a run-in strong wind (from 13 knots). Lastly, the sailor hikes leaning backwards on the close-hauled course with strong winds and in the changes from windward to leeward(tacking) (Felici et al., 1999; Blackburn, 2006; and Sekulic et al., 2006) (Figure 2). 


\section{International Journal of Sports Science and Artis}

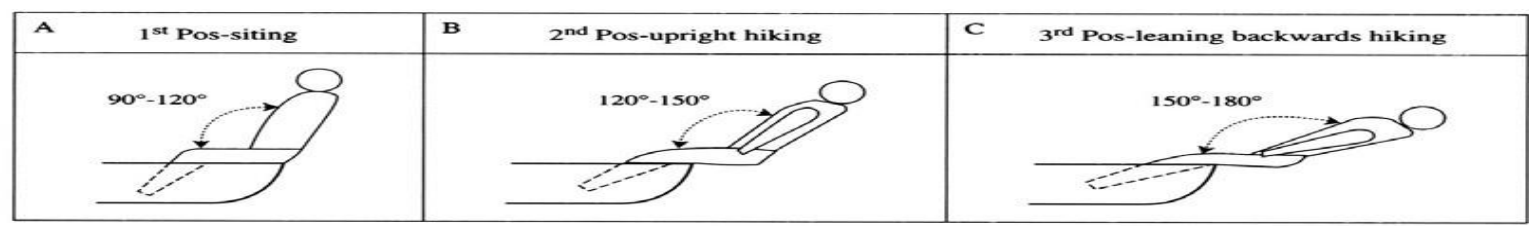

Figure 2. Conventional hiking positions (by Sekulic et al., 2006)

Throughout racing the main factors affecting the racing total sailing-time; time of hiking sustainability and the efficiency of hiking posture (Aagaard et al., 2007).

Blackburn and Hubinger 2015 reported that in dinghy sailors, the correlationbetween hiking resistance and performance in races was 0.82 .

Core muscles have been suggested not only to protect the spine from excessive force, but also to play an important role in body stabilization and force generation (Kibleret al., 2006 ; Sharrock et al., 2011). Specially during sporting activities like hiking in sailing (Bourgois et al., 2016). Core stability, strength and endurance are the most important core abilities that ensure spine stability for force production and injury prevention (Huxel Bliven \& Anderson, 2013). Core stability indicates the spine stability and verifies the efficiency of biomechanical function for maximizing generatedforce (Hibbs et al., 2008 ; Tong et al., 2014). Core strength refers to the muscular ability to stabilize the spine through contractile forces and intra-abdominal pressure,actively controlling spine stability through co-activation of the trunk muscles (Akuthota \& Nadler, 2004). Core endurance is the most crucial component in core training (Leetun et al., 2004) because it supports core muscles in maintaining an efficient position for trunk (Hung et al., 2019) indicates that core endurance is important to spinal stability during sustained work. (Lopez et al., 2016) indications the positive relationship that exists between both core endurance and functioning kinematics. 
Functional strength exercises provide power improvement in a way which is very specific to the required technique involving same type of muscular contraction usedin the skill execution while exercising and develop strength and flexibility in the actual skill same (ROM) (Carter et al., 2007; Hibbs et al., 2008; Sekir et al., 2007), The most functional strength exercise for any certain movement is the real movement skill itself (Winwood et al., 2015). Where a particular exercise falls on this continuum depends upon how well it meets the criteria for a functional movement for a particular skill, moreover prevent the load interfering with technique(Okada, Huxel, \& Nesser, 2011). Through researcher observation and follow up with laser sailors' levels as member of technical committee and as board member with national team training programs, lack of functional core exercises during training program even though the importance of such specific exercise for laser sailors. Furthermore, few studies observed the effects of core function training in sailing. accordingly, the objective of the study is to examine the effects of functional core conditioning training on hiking at sailing radial.

\section{Material and MethodsSubject}

Ten competitive nationally male with a minimum of 2 years competition experience. (mean \pm SD: age $18.5 \pm$ 3years, weight $59.3 \pm 6.7 \mathrm{~kg}$, height $1.68 \pm 0.07 \mathrm{~m}$ ) participated in this study. Subjects were involved $(n=10)$ were volunteered to participate in the current study. Sailors performed 8-weeks of functional coreconditioning training, 3 sessions per week, average of 20-30 min per session for corestability, strength and endurance program, using stable and non-stable surfaces by using Swiss ball, BOSU ball, balance board, hiking bench and laser boat simulator,elastic band, weights, resistance, mainsheets, buckles. Participants also performed a 
supervised warming up and stretching routine at the end of each training session, during the 8-week intervention. The program focused on specific functional core stability, strength, and endurance, as well as enhancement of sailing technical skills for hiking which has a positive influence on boat speed. Inclusion criteria for all subjects required each participant to be a healthy sailor player, no history of knee, shoulder, upper or lower extremity injuries or surgery for the past 8 weeks, and no participation in a specific functional core training program the last 4 weeks before the study. The sailors and their parents wrote informed consent.

\section{Experimental setup}

This study examined the effect of functional core conditioning training which can affect hiking performance on hiking at sailing radial. Ten male laser radial sailors volunteered to participate in the applied program to enhance core strength $\&$ improve hiking maneuvering in races. Players were advised for the testing sessions to avoid strength and endurance training two days before test.

\section{Functional Core Conditioning Training}

Hiking Performance depends on both eccentric and concentric contraction strength and isometric muscle strength as the movement is not solely characterized by static body postures, but also includes dynamic small-amplitude hiking movements. The most effective hiking postures place a large load on the knee extensor muscles. Therefore, the program was designed according to nature of hiking which depends on functional hiking exercises that include both static and dynamic muscle strength. Program designed progressively through three main phases to enhance hikingposition angel from (150-180) (Table 1\&2). Each phase has its own target; first phase focused on static isometric exercises on stable surface ( $1^{\text {st }}$ week), thendynamic isokinetic exercises on stable surface had been added on second phase $\left(2^{\text {nd }} \& 3^{\text {rd }}\right.$ week $)$, after, dynamic exercises on unstable surface focused had been added to 


\section{International Journal of Sports Science and Arts}

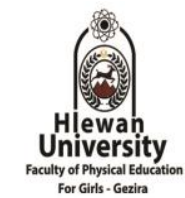

third phase $\left(4^{\text {th }}-8^{\text {th }}\right.$ week $)$. Each session included a 10-15 min standardized dynamic warmup, and approximately 20-30 min of functional core conditioning training using stable and non-stable surfaces by using Swiss ball, BOSU ball, elastic band, weights, resistance, mainsheets, buckles, balance board, hiking bench and laser boatsimulator and 10 min cooling down (Table 3). More than 90\% attendance of the training was obligatory in order to be included in the study analyses.

Table 1. Main and Secondary Tools \& Equipment

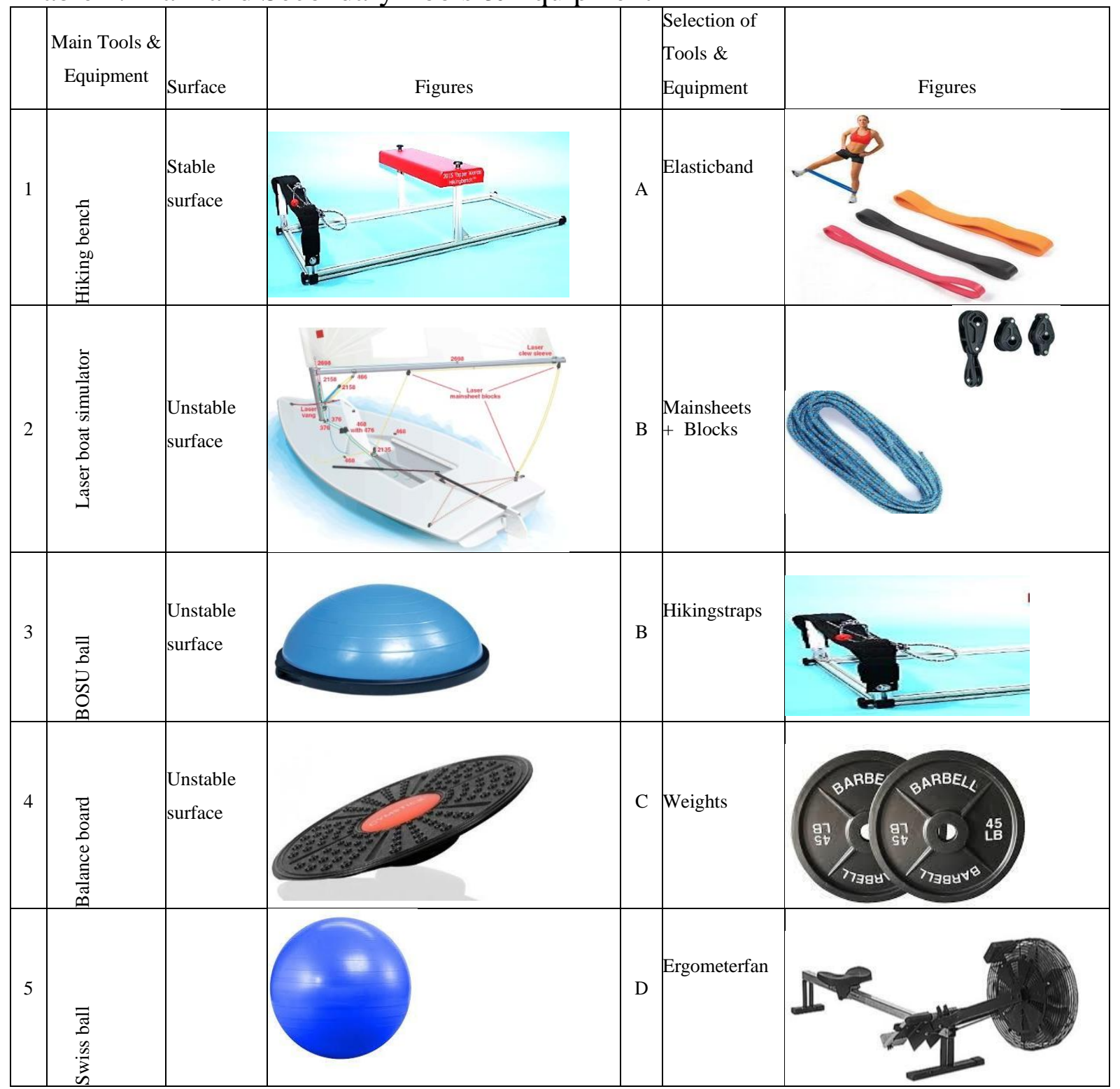




\section{International Journal of Sports Science and Arts}

Table 2. Core Functional Conditioning Training Stages

\begin{tabular}{|c|c|c|c|}
\hline Stages & Weeks & Muscle strength & Surface \\
\hline & & Isometric(Static) & \\
\hline Stage one & $1^{\text {st }}$ Week & & Stable \\
\hline Stage two & $2^{\text {nd }} \& 3^{\text {rd }}$ week & $\begin{array}{l}\text { Concentric } \\
\text { Isokinetic } \\
\text { (Dynamic) }\end{array}$ & Unstable \\
\hline Stage three & $4^{\text {th }}$ to $8^{\text {th }}$ week & $\begin{array}{l}\text { Concentric } \\
\text { Isokinetic } \\
\text { (Dynamic) }\end{array}$ & Unstable \\
\hline
\end{tabular}

All exercises were designed by using stable surfaces (hiking bench) then non-stable surfaces (Swiss ball, BOSU ball, balance board, and laser boat simulator) by using functional training exercises using (elastic band, foot strap, weights, mainsheets andblocks).

Program was well demonstrated and explained correctly to all sailors with the righttechniques before training period started. One experimental group trained on the applied functional core conditioning training program for 8-weeks, 3 times per weekintervention; characterized by strong functional eccentric and concentric contractions of the working group muscles including quadriceps, hamstrings, abdominal and paravertebral muscles (Figure 3). 


\section{International Journal of Sports Science and Arts}

Table 3. Core Functional Conditioning Training

\begin{tabular}{|c|c|c|c|c|c|c|c|c|c|c|c|c|}
\hline \multirow{2}{*}{$\begin{array}{l}\text { Week } \\
\text { Days }\end{array}$} & \multicolumn{3}{|l|}{1 st $\& 2^{\text {nd }}$} & \multicolumn{3}{|c|}{$3 \mathrm{rd} \& 4^{\text {th }}$} & \multicolumn{3}{|c|}{ 5th \& 6th } & \multicolumn{3}{|c|}{ 7th \& 8th } \\
\hline & Reps/ time & Sets & $\begin{array}{l}\text { Rest } \\
(\mathrm{sec})\end{array}$ & $\begin{array}{l}\text { Reps/ } \\
\text { time }\end{array}$ & Sets & Rest & $\begin{array}{l}\text { Reps/ } \\
\text { time }\end{array}$ & Sets & Rest & $\begin{array}{l}\text { Reps/ } \\
\text { time }\end{array}$ & Sets & Rest \\
\hline Sunday & $15 / 20$ & 2 & $\begin{array}{c}60 \\
(1: 3) \\
\end{array}$ & $20 / 30$ & 3 & $\begin{array}{c}60 \\
(1: 2) \\
\end{array}$ & $25 / 40$ & 2 & $\begin{array}{r}135 \\
(1: 3) \\
\end{array}$ & $30 / 50$ & 4 & $\begin{array}{c}25 \\
(2: 1) \\
\end{array}$ \\
\hline $\begin{array}{l}\overrightarrow{8} \\
8 \\
6 \\
8 \\
8 \\
0 \\
0 \\
0 \\
0\end{array}$ & \multicolumn{2}{|l|}{$\begin{array}{l}1(20 \mathrm{sec}) \\
1 \mathrm{~A} \\
1 \mathrm{~B}+\mathrm{C} \\
1 \mathrm{C} \\
1 \mathrm{D}\end{array}$} & & \multicolumn{3}{|c|}{$\begin{array}{l}1 \\
1 \mathrm{~A} \\
1 \mathrm{~B}+\mathrm{C} \\
1 \mathrm{C}\end{array}$} & \multicolumn{2}{|l|}{3} & & $\begin{array}{l}3 \\
4 \\
5 \\
3 \\
4 \\
5\end{array}$ & 25 mins & \\
\hline 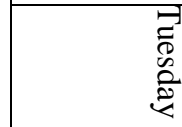 & $20 / 30$ & 2 & $\begin{array}{c}60 \\
(1: 2)\end{array}$ & $25 / 40$ & 3 & $\begin{array}{c}135 \\
(1: 3)\end{array}$ & $20 / 30$ & 2 & $\begin{array}{c}60 \\
(1: 2)\end{array}$ & $25 / 40$ & 4 & $\begin{array}{c}135 \\
(1: 3)\end{array}$ \\
\hline $\begin{array}{l}7 \\
8 \\
8 \\
0 \\
8 \\
8 \\
8 \\
\Xi \\
0 \\
0 \\
0 \\
0\end{array}$ & $\begin{array}{ll}1 \\
1 \mathrm{~A} \\
1 \mathrm{~B}+\mathrm{C} \\
1 \mathrm{C} \\
1 \mathrm{D} \\
2 \\
2 \\
2 \\
2 \\
2 \\
2\end{array}$ & & & $\begin{array}{l}1 \\
1 \\
2 \\
2 \\
3 \\
3\end{array}$ & mins & & $\mid \begin{array}{l}1 \\
1 \mathrm{~A} \\
1 \mathrm{~B}+\mathrm{C} \\
1 \mathrm{C} \\
1 \mathrm{D} \\
30 \mathrm{~min}\end{array}$ & & & $\begin{array}{l}3 \\
4 \\
5 \\
3 \\
4 \\
5\end{array}$ & mins & \\
\hline 总 & $15 / 20$ & 3 & $\begin{array}{c}60 \\
(1: 3)\end{array}$ & $20 / 30$ & 4 & $\begin{array}{c}90 \\
(1: 3)\end{array}$ & $25 / 35$ & 2 & $\begin{array}{r}115 \\
(1: 3)\end{array}$ & $30 / 50$ & 4 & $\begin{array}{c}25 \\
(2: 1)\end{array}$ \\
\hline 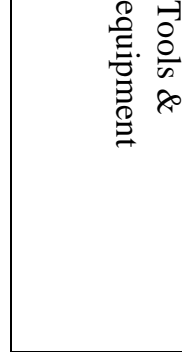 & $\begin{array}{l}1 \\
1 \mathrm{~A} \\
1 \mathrm{~B}+\mathrm{C} \\
1 \mathrm{C} \\
1 \mathrm{D} \quad 20 \mathrm{mir}\end{array}$ & ns & & $\begin{array}{l}1 \\
1 \\
2 \\
2 \\
3 \\
3\end{array}$ & & & $\begin{array}{l}2 \\
3 \\
4 \\
3 \\
4 \\
5\end{array}$ & 25 & & $\begin{array}{l}3 \\
4 \\
5 \\
3 \\
5 \\
5\end{array}$ & & \\
\hline
\end{tabular}



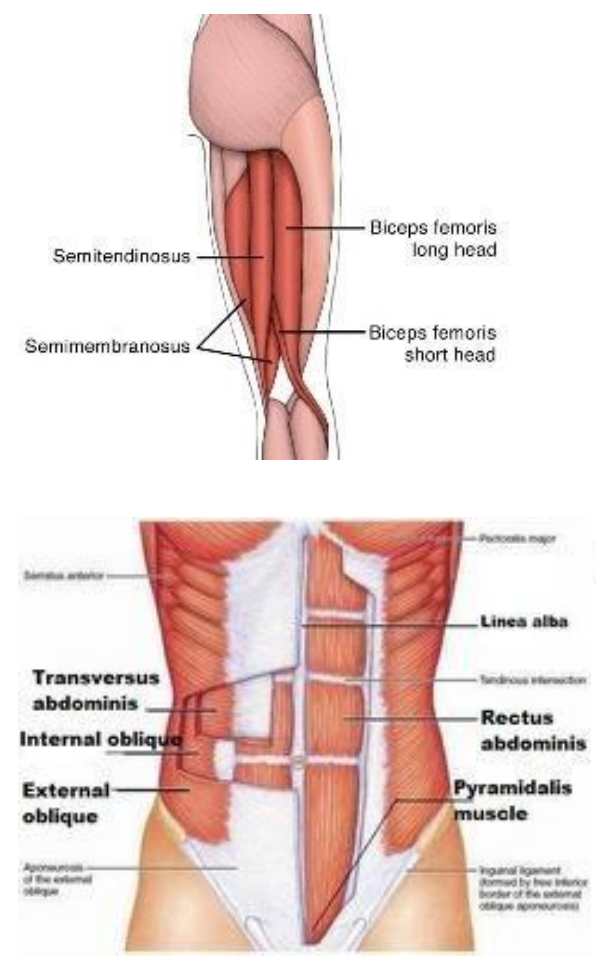

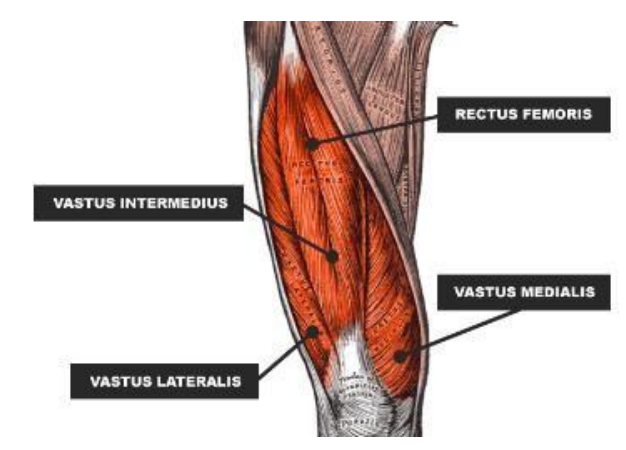

\section{PARAVERTEBRAL MUSCLES}
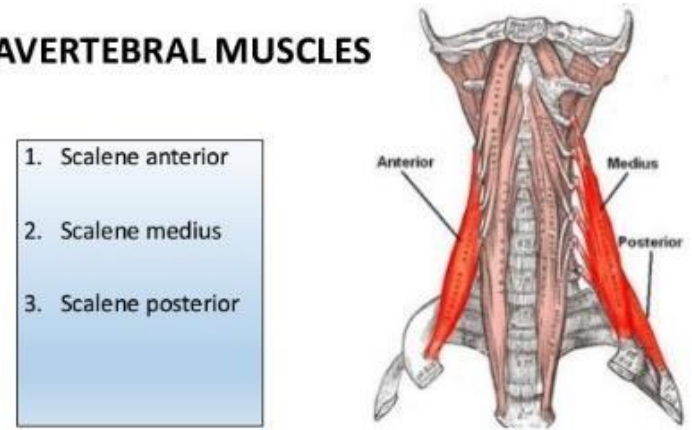

Figure 3. Hiking Working Muscles

\section{Core strength and stability test}

Core test applied on all sailors after 15 minutes waring up, the test contains 9 stages and at the end of the timing of the test stages had been recorded when sailors were unable to continue with the correct body position or were unable to continue with the test. The objective of this test is to monitor the improvements of core strength, stability and endurance. Requirement for the assessment will be flat surface, mat anda watch with second counter.

Plank is the starting position for the test that body is parallel to the ground with trunk rigid, straight and unbend, resting weight on both toes and forearms without saggingor twisting the body (Hung et al., 2019). First stage, hold for 60 seconds in plank position with elbows on the floor (starting position). Second, lift the right arm off the floor and hold for 15 seconds, third, return the right arm to the floor and lift the left arm off the floor then hold for 15 seconds, fourth, return the left arm to the 
ground and lift the right leg off the floor then hold for 15 seconds, fifth, Return the right leg to the ground and lift the left leg off the floor then hold for 15 seconds, sixth, lift the left leg and the right arm off the floor then hold for 15 seconds, seventh,Return your left leg and the right arm to the floor then hold for 15 seconds, eighth, lift your right leg and the left arm off the floor then hold for 15 seconds, ninth, returnto the plank exercise position (elbows on the floor) then hold this position for 30 seconds. Repeat previous stages by holding all for 15 seconds each and record timetill sailors be unable to either continue with the test or to uphold the right body position (Kibler et al., 2006 ; Sharrock et al., 2011).

\section{Statistical Analysis}

All data are presented as mean $( \pm \mathrm{SD})$. Paired $t$ tests were used to compare mean differences between pre- and post-test data for the experimental group, the level of significance used was $\mathrm{p}<0.05$. Statistical analyses were performed using the SPSS version 20 (SPSS Inc., Chicago, IL) software. In addition, improvement ratios were analyzed.

\section{Results}

Table 4. Individual characteristics of the sailors. Data are means $( \pm \mathrm{SD})$.

\begin{tabular}{c|c|c}
\hline Age (years) & Height $(\mathrm{m})$ & Weight $(\mathrm{kg})$ \\
\hline $18.5 \pm 3$ & $1.68 \pm 0.07$ & $59.3 \pm 6.7$ \\
\hline
\end{tabular}

Mean ( \pm SD) of the individual characteristics of the sailors are presented in Table 4 .

Table 5. Mean ( \pm SD) core test, between pre-test and post-test

\begin{tabular}{c|c|c|c|c}
\hline Test & Pre-test & Post-test & P value & Progress \% \\
\hline Core test & $2.38 \pm 0.09$ & $3.72 \pm 0.33$ & .000 & $12.20 \%$ \\
\hline
\end{tabular}

Mean $( \pm \mathrm{SD})$ of core test comparisons between pre-test and post-test measurements for the training group are shown in Table 5. 


\section{International Journal of Sports Science and Arts}

Table 5 shows that there was a significant difference in the core test for the training group $(\mathrm{p}=0.000)$ after the intervention, with a progress percentage of $(12.20 \%)$.

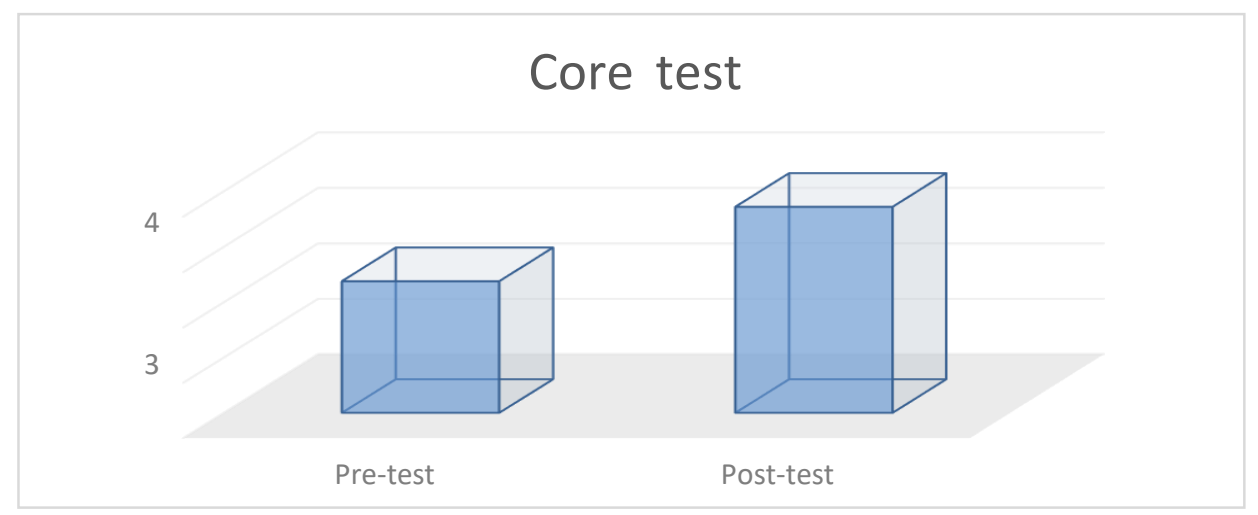

Figure 4: Core test comparisons between pre-test and post-test measurements forthe training group

\section{Discussion}

The aim of the study was to examine the effects of functional core conditioning training on hiking at sailing laser, findings of the study were presented for core testas before and after applied functional training program.

Data showed as presented in table 2, a positive significant difference in core test, $p$ value equal .000 with a progress percentage of $12.20 \%$. These positive differences reflect sailors' adaptation to the applied functional core training program, which support the main aim of the study.

(Willson et al., 2005) supported the finding of the study; that optimal force production tolerated by core muscles, that justify support, control, and move 
extremities. Also (Blagrove et al., 2018) found out that greater improvements in core muscles endurance, economy and performance after 8-week core training.

Since hiking is very vital skill in upwind to stabilize the boat while maintaining optimal boat speed sailing particularly in elite laser sailing (Putnam, 1979; Chicoy \& Encarnación-Martínez, 2015) and Counterbalancing the boat tilting instantly that's result from the wind in the sail is a must (Castagna \& Brisswalter, 2006). Utilizing proper force needed to keep the boat upright, Laser sailor's feet hooked under the toe strap close to the centerline of the boat keeping the upper limb over theedge of the boat (Putnam, 1979; Aagaard et al., 2007). Therefore, suitable core exercise may result in an enhancement in core strength, stability and endurance, andimprove efficiency of boat movement (Hung et al., 2019).

\section{Recommendation}

1-Study conducted on male sailors; more research should be carried out on females.

2-Study conducted on Laser Radial; more research should be carried out on other classes.

3- Core tests were used, further technical tests should be applied.

4- Other variables research should be carried out that might affect boat speed. References

1. Aagaard, P., Beyer, N., Simonsen, E. B., Larsson, B., Magnusson, S. P., \& Kjaer, M. (2007). Isokinetic muscle strength and hiking performance in elite sailors. Scandinavian Journal of Medicine \& Science in Sports, 8(3), 138144. https://doi.org/10.1111/j.1600-0838.1998.tb00183.x

2. Akuthota, V., \& Nadler, S. F. (2004). Core strengthening. Archives of Physical Medicine and Rehabilitation, 85(3 Suppl 1), S86--92. Retrievedfrom http://www.ncbi.nlm.nih.gov/pubmed/15034861

3. Blackburn, M. (1994). Physiological responses to $90 \mathrm{~min}$ of simulateddinghy sailing. Journal of Sports Sciences, 12(4), 383-390. https://doi.org/10.1080/02640419408732185 


\section{International Journal of Sports Science and Art's}

4. Blagrove, R. C., Howatson, G., \& Hayes, P. R. (2018). Effects of Strength

Training on the Physiological Determinants of Middle- and Long-Distance

Running Performance: A Systematic Review. Sports Medicine, 48(5),

1117-1149. https://doi.org/10.1007/s40279-017-0835-7

5. Bojsen-Møller, J., Larsson, B., \& Aagaard, P. (2015). Physical requirementsin

Olympic sailing. European Journal of Sport Science, 15(3), 220-227.

https://doi.org/10.1080/17461391.2014.955130

6. Bourgois, J. G., Callewaert, M., Celie, B., De Clercq, D., \& Boone, J. (2016).

Isometric quadriceps strength determines sailing performance and

neuromuscular fatigue during an upwind sailing emulation. Journal of

SportsSciences, 34(10), 973-979.

https://doi.org/10.1080/02640414.2015.1082613

7. Callewaert, M., Boone, J., Celie, B., De Clercq, D., \& Bourgois, J. G. (2015).

Indicators of sailing performance in youth dinghy sailing. European

Journal of Sport Science, 15(3), 213-219.

https://doi.org/10.1080/17461391.2014.905984

8. Carter, A. B., Kaminski, T. W., Douex, A. T., Knight, C. A., \& Richards, J.

G. (2007). Effects of high volume upper extremity plyometric training on throwing

velocity and functional strength ratios of the shoulder rotators in collegiate

baseball players. Journal of Strength and Conditioning Research,21(1),

208-215. https://doi.org/10.1519/R-19315.1

9. Castagna, O., \& Brisswalter, J. (2006). Assessment of energy demand in

10.Laser sailing: influences of exercise duration and performance level.

European Journal of Applied Physiology, 99(2), 95-101.

https://doi.org/10.1007/s00421-006-0336-0 


\section{International Journal of Sports Science and Arts}

11. Chicoy, I., \& Encarnación-Martínez, A. (2015). DETERMINING FACTORS IN THE PERFORMANCE OF HIKING IN DINGHY

SAILING: A LITERATURE REVIEW. Retrieved from https://www.semanticscholar.org/paper/DETERMINING-FACTORS-INTHE-PERFORMANCE-OF-HIKING-IN-Chicoy-EncarnaciónMartínez/dac161a848fd9b0a4adcf906ec57e9539710b71f

12. Cunningham, P., \& Hale, T. (2007). Physiological responses of elite Laser sailors to 30 minutes of simulated upwind sailing. Journal of Sports Sciences, 25(10), 1109-1116. https://doi.org/10.1080/02640410601165668

13. Day, A. H. (2017). Performance Prediction for Sailing Dinghies.

Retrieved from https://pdfs.semanticscholar.org/58ad/9cf50135e5b88fc932de47c69f5443 8d017a.pdf

14. Hibbs, A. E., Thompson, K. G., French, D., Wrigley, A., \& Spears, I. (2008). Optimizing Performance by Improving Core Stability and Core Strength. Sports Medicine, 38(12), 995-1008. https://doi.org/10.2165/00007256-200838120-00004

14.Hung, K.-C., Chung, H.-W., Yu, C. C.-W., Lai, H.-C., \& Sun, F.-H. (2019). Effects of 8-week core training on core endurance and running economy. PloS One, 14(3), e0213158. https://doi.org/10.1371/journal.pone.021315815.Huxel

Bliven, K. C., \& Anderson, B. E. (2013). Core stability training for injury prevention. Sports Health, 5(6), 514-522.

https://doi.org/10.1177/1941738113481200

16. Kibler, W. Ben, Press, J., \& Sciascia, A. (2006). The Role of Core Stability in Athletic Function. Sports Medicine, 36(3), 189-198. https://doi.org/10.2165/00007256-200636030-00001 


\section{International Journal of Sports Science and Arts}

17. Larsson, B., Beyer, N., Bay, P., Blønd, L., Aagaard, P., \& Kjær, M. (1996).

Exercise Performance in Elite Male and Female Sailors. International Journal of

Sports Medicine, 17(07), 504-508. https://doi.org/10.1055/s-2007972886

18. Leetun, D. T., Ireland, M. L., Willson, J. D., Ballantyne, B. T., \& Davis, I.

M. (2004). Core stability measures as risk factors for lower extremity injuryin athletes. Medicine and Science in Sports and Exercise, 36(6), 926-934.

Retrieved from http://www.ncbi.nlm.nih.gov/pubmed/15179160

19. Lopez, S., Bourgois, J. G., Tam, E., Bruseghini, P., \& Capelli, C. (2016). Cardiovascular and Metabolic Responses to On-Water Upwind Sailing in Optimist Sailors. International Journal of Sports Physiology and Performance, 11(5), 615-622. https://doi.org/10.1123/ijspp.2015-0380

20. Okada, T., Huxel, K. C., \& Nesser, T. W. (2011). Relationship Between Core Stability, Functional Movement, and Performance. Journal of Strengthand Conditioning Research, 25(1), 252-261. https://doi.org/10.1519/JSC.0b013e3181b22b3e

21. Rodek, J., Sekulic, D., \& Kondric, M. (2012). Dietary supplementation and doping-related factors in high-level sailing. Journal of the International Society of Sports Nutrition, 9(1), 51. https://doi.org/10.1186/1550-2783-9-51

22. Sekir, U., Yildiz, Y., Hazneci, B., Ors, F., \& Aydin, T. (2007). Effect of isokinetic training on strength, functionality and proprioception in athletes with functional ankle instability. Knee Surgery, Sports Traumatology, Arthroscopy, 15(5), 654-664. https://doi.org/10.1007/s00167-006-0108-8

23. Sharrock, C., Cropper, J., Mostad, J., Johnson, M., \& Malone, T. (2011). A pilot study of core stability and athletic performance: is there a relationship? 


\section{International Journal of Sports Science and Arts}

International Journal of Sports Physical Therapy, 6(2), 63-74. Retrievedfrom http://www.ncbi.nlm.nih.gov/pubmed/21713228

24. Sjøgaard, G., Inglés, E., \& Narici, M. (2015a). Science in sailing: Interdisciplinary perspectives in optimizing sailing performance. EuropeanJournal of Sport Science, 15(3), 191-194. https://doi.org/10.1080/17461391.2015.1008583

25. Sjøgaard, G., Inglés, E., \& Narici, M. (2015b). Science in sailing: Interdisciplinary perspectives in optimizing sailing performance.

EuropeanJournal of Sport Science, 15(3), 191-194.

https://doi.org/10.1080/17461391.2015.1008583

26. Tan, B., Aziz, A. R., Spurway, N. C., Toh, C., Mackie, H., Xie, W., ... Teh,

K. C. (2006). Indicators of maximal hiking performance in Laser sailors.European Journal of Applied Physiology, 98(2), 169-176. https://doi.org/10.1007/s00421-006-0260-3

$27 . \quad$ Tong, T. K., Wu, S., Nie, J., Baker, J. S., \& Lin, H. (2014). The occurrence of core muscle fatigue during high-intensity running exercise and its limitation to performance: The role of respiratory work. Retrieved July 8, 2019, from

https://www.researchgate.net/publication/262021423_The_Occurrence_o f_Core_Muscle_Fatigue_During_High-

Intensity_Running_Exercise_and_its_Limitation_to_Performance_The_R ole

_of_Respiratory_Work

28. Willson, J. D., Dougherty, C. P., Ireland, M. L., \& Davis, I. M. (2005).

CoreStability and Its Relationship to Lower Extremity Function and Injury.

Journal of the American Academy of Orthopaedic Surgeons, 13(5), 316-325. 


\section{International Journal of Sportis Science and Arts}

https://doi.org/10.5435/00124635-200509000-00005

29. Winwood, P. W., Cronin, J. B., Posthumus, L. R., Finlayson, S. J., Gill, $\mathrm{N}$.

D., \& Keogh, J. W. L. (2015). Strongman vs. Traditional ResistanceTraining Effects on Muscular Function and Performance. Journal of Strength and Conditioning Research, 29(2), 429-439. https://doi.org/10.1519/JSC.000000000000062 